Library Collections, Acquisitions, \& Technical Services, 1999, Vol. 23, No. 3, p. 321-338.

ISSN: 1464-9055

http://www.sciencedirect.com/

http://www.sciencedirect.com/science/journal/14649055/23/3

http://dx.doi.org/10.1016/S1464-9055(99)00074-3

(C) 1999 Elsevier Science Ltd.

\title{
MAKING CHOICES: VENDORS AND AGENTS IN THE ASSESSMENT PROCESS
}

\author{
CAROL PITTS DIEDRICHS
}

Note: This paper was based on a presentation to the 10th annual Collection Symposium held at the University of Minnesota on May 18, 1998, "Making Choices: Philosophies and Practices in Collection Assessment and Evaluation."

\section{INTRODUCTION}

One of the reasons I was invited to speak today was because of a presentation I made in 1992 at the Oklahoma Acquisitions Conference. The title of that presentation and subsequent article was "In Support of Collection Assessment: The Role of Automation in the Acquisitions and Serials Departments" [1]. In my introduction to that article, I cited a 1987 Charleston Conference presentation by Joseph Barker. Barker identified "three shaping forces in store for most acquisitions librarians in the 13 years leading to the year 2001: the rise of collection management, constraining forces from budgets, and the ramifications and potential of automation." Joe identified four implications of these changes for the acquisitions department: First, we are inextricably tied to vendor services, and especially to selection support such as approval plans. Second, acquisitions is inextricably linked to automation (its own automated system and vendors' automation, plus online catalogs, online utilities, and new bigger databases and directories of publishers, wholesalers, and publications). Third, since collection managers will be doing more with less, they will call upon acquisitions to be even more accurate and to do even more comprehensive pre-order and follow up work. And fourth, everyone will continue to look everywhere for ways to cut staff even further [2].

Amazingly enough, Barker's predictions are still applicable today; collection management has become very important to libraries, budget constraints continue to plague all of us, and the potential and now, reality, of automation has been dramatic. Barker can been forgiven for not predicting the Web and the rise of electronic journals, but clearly those specific manifestations of automation potential have changed dramatically the library world. His expectations for acquisitions are equally true; acquisitions is even more dependent on vendor services and local library systems than even Barker could probably have imagined. Much of that dependence is a result of the staff reductions seen over the past decade.

In addition, the use of vendor services has shifted somewhat as a result of the type of automation available. In the past, requests were submitted to a vendor, and they vendor produced reports for the library such as a list of titles in a particular subject field or within a particular date 
range. In addition, there were regular reports that were sent systematically to libraries such as approval return reports with specific titles indicated, reasons for the return, and a statistical analysis based on the library's approval profile. All of these forced the library to work on the vendor's time schedule. As Dana Alessi of Baker \& Taylor predicted in 1992, the advantages of today's technologies include allowing the library to select its own parameters, having online access to the entire vendor database, and performing the assessment at the library's convenience [3]. As many of the examples in this paper will reveal, many vendor services still require the vendor to provide the information either one-time or on an ongoing basis. But, the biggest change since 1992 is that libraries have many tools more readily available that can be used at the library's convenience.

\section{BIBLIOGRAPHER'S WORKSTATION}

In 1992, there was considerable discussion about the concept of a bibliographer's workstation that would provide seamless, transparent access to a number of tools supporting the acquisitions and collection management process. That vision has evolved with the emergence of the World Wide Web. Previously the expectation was that all of these tools would reside in software on the local PC on the bibliographer's desk. Those tools are now available to the bibliographer on the desktop, but are not necessarily integrated into a single piece of software. Instead, they reside as individual tools on the Web sites of various vendors and agents. It was clear from early efforts with expert systems that no computer could replace the expertise of a bibliographer. Instead, tools have been developed that improve the bibliographer's efficiency, reduce the number of errors (such as duplicate purchases), and provide information to make better informed judgements. The most common example is the Web version of the vendor's database that many vendors are making available today.

For example, through Academic Book Center's BookBag, libraries can:

- search the vendor's title database,

- place orders directly in the database and review existing orders,

- place orders for titles not in the database,

- cancel orders,

- review approval titles before shipment,

- forward information such as notification slips to other interested faculty and staff, and

- order approval titles announced on notification slips [4].

One of the most useful things about this system is its flexibility for allowing the library to work in its local database and forward information to Academic or to work in the Academic database. In Ohio State's case, as an Innovative Interfaces (III) system user, staff could place orders in the BookBag system prior to entering them in III. Staff could tag the title for purchase in BookBag by clicking on an icon. A file is created at the end of the day that can be retrieved by FTP and loaded into the III system. Then, the order creation process completed in III and III would send a short record to Academic with their system number and the III purchase order number. This information is linked to the order tagged earlier so that it can be cited properly on the invoices. Book Bag also includes 4 years worth of approval history. Individual selectors can search the system covering any date range and limit searches by books to be sent automatically, form selections, date added to the database etc. As a result, the selector can view titles that are expected 
on approval, can review notification slips online and place orders, and can review new additions to the database (based on the date) [5].

In the past, one of the foremost concerns in acquisition was the elimination of duplicate effort. This solution is elegant and appealing because it addresses library concerns about the possible duplicate work involved in using a local system and a vendor system. However, the multi-tasking capabilities of today's PC workstations as well as cut and paste technology may be changing this objection to duplicate work. Most Acquisitions Departments have resisted implementation of systems that are not fully integrated with the local system's acquisitions module. As a result, most of these new databases from vendors are fully integrated. This automated approach eliminates duplicate work by transferring the information between systems transparently. But, current technology also makes it possible to cut and paste information between the library's online system and the vendor database. In this model, the library can actually do duplicate work (placing the order in the local system and in the vendor's system) efficiently. At Ohio State, Yankee Book Peddler's (YBP) GOBI system is being implemented as a part of OhioLINK's statewide approval program. In an amazing shift in philosophy, we actually believe that it will be more efficient and timely to open simultaneous sessions on the III local system and the GOBI system and place orders in both systems. Although it is clearly redundant effort, this approach eliminates the time delay inherent in entering the information in one system, transferring it, and then retransmitting. Because 45 collection managers will be using this system to tag orders, the need for very up-to-the minute information is foremost in our decision making. The multitasking capabilities of the PCs and cut and paste technology make this a feasible alternative. As mentioned above, OhioLINK, Ohio's statewide consortium, has implemented a statewide approval project that would include a version of the bibliographer's workstation. For this project OhioLINK's vision includes a contract that would

be signed by OhioLINK on behalf of all participating libraries with a single vendor for the provision of English language approval plans. A discount based on the size of this contract would be equal to or an improvement over existing approval arrangements. Libraries not involved in approval plans would be able to place firm orders via the same vendor at the same discount as approval materials. Libraries would also have access to shelf-ready options, PromptCat services, and standing orders plans from the same vendor as desired (but likely at a different yet consortial pricing structure).... Approval profiles would be controlled by each local library. The profiles would be accessible to all OhioLINK institutions via a Web-based vendor tool. This tool would enable collection managers at each local library to look at their own profiles online as well as those of their colleagues in other OhioLINK libraries. Staff could search and view a list of books that match their profile and see what action had been taken for their library on each title, e.g., received as book, notification slip, etc. as well as the action taken for other OhioLINK libraries. In one possible scenario, forthcoming titles would also be pre-profiled by the vendor to determine probable action. This information on action expected could appear in the database as soon as a title was identified for inclusion on the approval system (prior to publication). Collection managers would be able to review titles and mark for shipment on approval. Staff would be able to place firm orders online, and that data could be transferred electronically into the Innovative Interfaces system.

The system would keep track of the number of copies of each title profiled for or ordered by OhioLINK libraries. As a result of this calculation, the user could be alerted if their order surpassed a pre-defined threshold for copies but would not be prevented from placing the order or approval shipment flag $[6]$.

In implementing this system at OSU, very dramatic changes are occurring in the way monographic material is ordered. In the future, collection managers will be able to review their profiles online and manipulate them to see how changes would impact material to be shipped to them. In the past, such manipulations had to be performed by the vendor and were not extremely 
detailed. In the past, OSU had a very manual process for "ordering" titles against the approval plan that was very popular with collection managers. When they saw a title in a catalog well in advance of publication, they would send the order to Acquisition and an order would place for the title to be shipped on approval. Collection managers were very happy because they did not have to think about the title again. Acquisition was very unhappy because they had to keep track of who had "ordered" the title so that when it arrived and was put up on the approval shelf, that collection manager had first right to the title. The option was eventually eliminated because of the workload involved. With the implementation of the OhioLINK approval plan in January 1999, OSU plans to give collection managers online access to the vendor's Web database. They will be able to review titles online and "select" them for shipment in addition to titles that will come automatically as a result of the approval profile. By allowing them to do this work themselves and with information from the vendor about which titles they "selected" in this fashion, Acquisition will be able to reinstate this popular practice. OSU also anticipates considering how to allow the collection managers to place orders for the notification slips they receive.

As mentioned earlier, collection managers also will have access to information about what their colleagues across the state are selecting to inform their decision making. As the vision mentioned, OhioLINK has also explored the option of using an alerting system to advise individual libraries when they are purchasing the next copy of a title above a certain threshold. For example, if OSU places an order with the approval plan supplier and that is the 10th order placed in the state, OSU will be alerted to that information. The library will not be prevented from ordering the title but the alert will serve to remind them of the number of copies already available and whether they truly want to acquire an additional copy.

\section{VENDOR SERVICES}

\section{Monographic Services: Selection}

Collection assessment for academic libraries is usually performed many years after titles have been selected and acquired for the collection. Collection assessment has been defined as the degree of collation "between the collection and the selection policy, or the success of the collection in fulfilling user demands" [7]. The focus on this section, monographic services, may not on first appearance seem to relate to collection assessment. However, academic libraries have some lessons to learn from public library colleagues particularly as it relates to the last part of that definition: fulfilling user demands. Current monographic services used heavily by public libraries focus on user demand for popular titles.

As in the past, monographic vendors can provide generic or customized lists of titles in particular subject areas. These lists can be used to develop a previously undeveloped part of the collection, to support a new degree program, and to build an entire opening day collection such as the new Florida Gulf Coast University Library did. Academic libraries have used approval plans and their related notification slip programs for years to consistently develop portions of their collections without the burden of selecting title by title. Many libraries have taken this "approval" process a step further in recent years by receiving these materials shelf-ready with little or no review by collection managers.

In the public library area, central offices have created internal selection lists for their branch libraries to select from for years. For example, Julie Pringle, coordinator of collection development and acquisitions at Fairfax County Public Library in Virginia, uses Ingram's Advance Buyer Checklist to be alerted to high-demand adult titles. In addition, based on her 
library's profile, the checklist provides a suggested number of copies for purchase [8]. The Indianapolis-Marion County Public Library (IMCPL) [9] took the process of selection lists constructed by a vendor to new levels. This library implemented centralized selection for the main library and all branches. Much like an approval plan, the vendor provides material for the main library and its branches through automatic selection based on profiles. Again, for public libraries, vendors can draw on the sales history in the vendor's database for types of titles for a specific market. This is most effective "for collections of popular materials, where general popularity of an item is an accurate predictor of popularity in one's own library. Vendors who cater to both the library and the retail trade are perhaps best able to provide this kind of information" [10]. They can use information from book stores to predict demand in public libraries. For public libraries, these services have now been extended to cover the sound recording and video markets.

\begin{abstract}
At least two vendors offer automatic shipment programs of new recordings based on various Billboard charts. Others provide listings of titles by category (e.g., 'Opera-Complete,' 'Operas-Highlights,' 'Film/ Show Music') and/or in-stock listings from their warehouse. ... [For videos], At least one review source is interacting with a vendor by noting which reviewed titles are carried by the vendor. Other approaches include an automatic shipment program of top videos and a listing of videos that have sold best to libraries in a specific period of time [11].
\end{abstract}

When using a vendor for retrospective collection development services, i.e., to build a collection in a new area, the vendor's database should have an advantage over sources such as Books in Print because the vendor can supply availability information. The vendor can also limit the report to titles still in print in addition to the existence of given titles in a particular area.

\footnotetext{
Blackwell North America, for example, includes in its book entries Library of Congress subject information as well as cross references with the 6000 terms in its in-house subject thesaurus. Baker \& Taylor uses 7300 subject 'descriptors' and notes reviews from 400 sources such as $L J$ and even regional publications; Brodart indexes a similar amount of sources. Ingram generates many customized lists that will tell its clients what books in what subjects are selling where [12].
}

Requests for lists of titles can be extremely tailored. For example, one public librarian has asked for books dealing with the U.S. space program since 1989, in paperback, for grade six and under and prioritized in terms of quality of review. As a result of using these services, public librarians can achieve two all-important objectives: speed and anticipation.

Another tool, OCLC's Selection service [13], is designed to provide access to multiple resource files such as Books in Print and WorldCat for easy identification of materials to be ordered. In theory, this sounds good, but I would have to argue that in practice, I have found the information in monographic vendor databases to be much more useful than WorldCat or BIP. WorldCat provides bibliographic information but little in the way of reliable pricing and availability information. BIP does provide better pricing and availability information than WorldCat, but it is not updated as often as the vendor databases are, and with a vendor database, the source of the information (the act of actually ordering and supplying the title) is much more reliable. OCLC Selection does allow for the transfer of an OCLC record through the selector to the acquisitions department, but that same process can also be achieved using one of the new Web databases provided by vendors. OCLC has added records from vendors such as Puvill Libros, Otto Harras-sowitz, and Casalini Libri to its databases. This type of addition does provide advantages over the monographic vendor systems that are primarily US/UK-oriented. Ordering information is included in the 938 field, but it is likely to become dated very quickly. 


\section{Monographic Services: In-Print Titles}

As mentioned earlier, vendor reports have become more accessible. For example, YBP includes a service on its Web site that allows customers to create their own reports. Reports showing the number of books shipped to the library and the costs can be created online and sorted by LC or Dewey classification, fund code, publisher, or summary. The library selects the time period desired and can display the report online, can save it to a file, or print it. Report parameters can also be submitted online and then delivered when ready via e-mail. An approval plan profile report is also available that includes information on the overall profile, the publisher profile, and approval plan activity. The approval plan activity report includes the reason for returns as well as numbers and costs for material kept.

YBP has also done considerable work in the area of consortium support. They have developed several retrospective comparison reports to identify and analyze historical collection development patterns of member libraries. These include a shipment history and the existence of unique titles in each library sorted by imprint or LC class. This report indicates how many titles by a particular publisher or within a LC class were shipped to each library and how many were unique to the consortium. Of course, these reports are limited by the extent to which the individual libraries used the same vendor and for how high a percentage of their material. Additional comparative reports reveal whether a library has a particular publisher selected for books, notification slips, or nothing in their approval plan (see Figures 1 and 2). This comparison can also apply to the coverage of individual series titles. YBP is also working with consortia to evaluate goals such as "to collect at least $70 \%$ of the English-language books distributed in the U.S." In one three-library consortia, the definition of core collection permits at most two libraries to own a title. Above the core, only one member of the three needs to own a copy. YBP has also developed a "consortial viewpoint" that allows users in any of the consortial libraries to see the local history for their partners in a single search. The GOBI system also allows for a duplication alert that can be activated if YBP already has supplied a particular title to another library within the consortium [14]. YBP is also engaged in a project with three California State University libraries (Fullerton, Pomona, and Northridge) and WLN. WLN is using its collection analysis software on those three collections plus a universe of titles, or in this case, all of the titles in the GOBI database [15]. As the vendor selected for the OhioLINK statewide approval project, YBP will be developing additional tools in concert with OhioLINK to further the goals of that project. Those tools will undoubtedly be made available to other customers as well.

\section{Out-of-Print Book Services}

The ALA Midwinter Meeting of the ALCTS Out-of-Print Discussion Group focused on the revolution taking place in the out-of-print market as a result of the Web:

\footnotetext{
In pre-Internet times, many people did not attempt to search for OP books due to the slow, expensive, and cumbersome nature of the business. But the Internet has changed all that. Locating OP 'wants' is now quick, easy, and inexpensive. As a result, more people and institutions are turning to the Internet. Collectors are working on completing their collections with renewed vigor and many owners of review copies are selling off their stock. Currently demand is outstripping supply.... There are new players in the field who work almost exclusively through the Internet and do not maintain storefronts. Some existing dealers report that most of their income is now generated through Internet sales and several of them are giving serious thought to closing down their storefronts in order to reduce overhead [16].
} 
Books Shipped and Unique Titles Acquired within the Consortium

Sorted by Imprint

\begin{tabular}{|l|c|c|c|}
\hline & $\begin{array}{l}\text { Books to Library } \\
1\end{array}$ & Books to Library 2 & Books to Library 3 \\
\hline Shipped/Unique & Shipped/Unique & Shipped/Unique \\
\hline Abbeville & & & \\
\hline ABC-CLIO & $2 / 1$ & $1 / 0$ & $13 / 13$ \\
\hline Academic & $12 / 8$ & $8 / 7$ & $22 / 21$ \\
\hline Academy Group & $8 / 7$ & $4 / 33$ & $18 / 13$ \\
\hline Addison-Wesley & $3 / 2$ & $10 / 8$ & $5 / 5$ \\
\hline Adobe Press & $0 / 0$ & $0 / 0$ & $30 / 28$ \\
\hline Aldine de Gruyter & $3 / 3$ & $6 / 6$ & $2 / 2$ \\
\hline $\begin{array}{l}\text { Algonquin of Chapel } \\
\text { Hill }\end{array}$ & $1 / 1$ & $1 / 1$ & $1 / 1$ \\
\hline Allyn \& Bacon & $8 / 5$ & $1 / 0$ & $19 / 16$ \\
\hline Amadeus & $9 / 2$ & $6 / 1$ & $9 / 2$ \\
\hline Amer Inst of Physics & $2 / 1$ & $7 / 4$ & $7 / 5$ \\
\hline AMS Press & $1 / 0$ & $4 / 2$ & $7 / 5$ \\
\hline Basic Books & $13 / 4$ & $17 / 10$ & $37 / 25$ \\
\hline & & & $182 / 138$ \\
\hline & $68 / 38$ & $105 / 75$ & $76 \%$ \\
\hline & & & \\
\hline$\underline{\text { \% Unique within }}$ & $56 \%$ & $71 \%$ & \\
\hline Consortium & & & \\
\hline
\end{tabular}

[Main Menu] [Send Message] [Sign Off] [Help Contents]

Yankee Book Peddler

999 Maple Street, Contoocook, NH, 03229. USA

Tel: 800-258-3774 Fax: 603-746-5628

E-mail: service@ybp.com

\section{Figure 1.}




\section{Approval Presses with Book Coverage For At Least One Plan}

\begin{tabular}{|c|c|c|c|c|c|}
\hline Imprint Name & Library 1 & Library 2 & Library 3 & Library 4 & Library 5 \\
\hline Amadeus & B & B & B & B & $S$ \\
\hline Applause & $\mathrm{S}$ & B & $\mathrm{X}$ & $\mathrm{S}$ & $\bar{S}$ \\
\hline Back bay & $\mathrm{S}$ & B & $\mathrm{B}$ & B & $\mathrm{S}$ \\
\hline Basic Books & $S$ & $\mathrm{~B}$ & $\mathrm{X}$ & B & $\mathrm{S}$ \\
\hline Bay Press & B & B & B & $S$ & $\mathrm{~S}$ \\
\hline Berg & $\mathrm{B}$ & $\mathrm{B}$ & $X$ & $S$ & $S$ \\
\hline Black Sparrow & $\mathrm{B}$ & $\mathrm{B}$ & $\mathrm{X}$ & $S$ & $S$ \\
\hline Blackwell & S & B & $X$ & S & $S$ \\
\hline Cambridge UP & $S$ & B & $X$ & B & 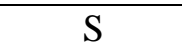 \\
\hline Columbia & S & B & $X$ & $\mathrm{X}$ & $S$ \\
\hline Faber amd Faber & $\mathrm{S}$ & $\mathrm{B}$ & $\mathrm{B}$ & $X$ & $\mathrm{~S}$ \\
\hline Fallen Leaf & $\mathrm{B}$ & $\mathrm{B}$ & $\mathrm{B}$ & $S$ & $S$ \\
\hline Fordham UP & $\mathrm{S}$ & $\mathrm{B}$ & $\mathrm{B}$ & $\mathrm{B}$ & $\mathrm{S}$ \\
\hline Free Press & S & B & $X$ & $\mathrm{~B}$ & $S$ \\
\hline Greenwood & $\mathrm{B}$ & B & $\mathrm{X}$ & $\mathrm{B}$ & $\mathrm{S}$ \\
\hline Harry Adams & $S$ & B & $\mathrm{X}$ & $\mathrm{S}$ & $\mathrm{S}$ \\
\hline Harvard & $S$ & $\mathrm{~B}$ & $\mathrm{X}$ & $\mathrm{B}$ & $\mathrm{S}$ \\
\hline $\begin{array}{l}\text { Holmes and } \\
\text { Meier }\end{array}$ & $S$ & B & $\mathrm{X}$ & B & $\mathrm{S}$ \\
\hline $\begin{array}{l}\text { Total Book } \\
\text { Instructions }\end{array}$ & 6 & 18 & 6 & 9 & 0 \\
\hline$\frac{\text { Unique Book }}{\text { Instructions }}$ & 0 & 3 & 0 & 0 & 0 \\
\hline
\end{tabular}

[Main Menu] [Send Message] [Sign Off \[Help Contents]

Yankee Book Peddler

999 Maple Street, Contoocook, NH, 03229, USA

Tel: 800-258-3774 Fax: 603-746-5628

Email: Service@yhp.com

Figure 2.

There are three sites which provide search engines for hundreds of small booksellers: Advanced Book Exchange (ABE): 〈http://www.abebooks.com>, Interloc: 
<http://www.interloc.com $>$, and Bibliofind: 〈http://www.bibliofind.com>. Theses services are the "electronic marketplaces where buyers and sellers can come together." The cost burden falls to the sellers who pays an initial membership fee and then a monthly and/or per-item-sold fee. Each service has over 1500 members and a high volume of sales. As a result, they can keep their fees low and provide free software to the sellers to maintain their inventory and to maintain individual Web pages for their companies. The inventory of each service numbers several million items. On the surface, the services appear very similar in format, but the overlap in bookstock is not great. Thus, libraries are well served to search all of the services when looking for a particular title. This will drive the fill rate even higher. There is no cost to access the services, search databases, and contact sellers. The searching capabilities of each service are similar including include author, title, and keyword, as well as combinations of those. Keyword searching is available and covers publisher, edition, subject/topic, binding, signatures, dust jacket, ISBN, etc. "ABE and Interloc allow customers to create want lists that are automatically rematched daily. ABE allows buyers to search sellers by country and to browse the inventory of a particular seller. Interloc has a page for posting recently missing or stolen books. Bibliofind provides links to weekly, online book auctions" [17].

In contrast:

MX Bookfinder [<http://www.mxbf.com $>$ ] is a completely different animal. It is a metasearch engine that searches across a number of OP and in-print book sites, including: ABE, Amazon, Bibliocity, Bibliofind, Cherry Valley Books, Interloc, and Powell's Bookstore. ... As an indication of the volume of business, Richard Weatherford reported that Interloc issues 50,000-100,000 matches daily. He said that there are about 25,000 OP dealers in North America, of which about 1,800 participate in Internet sales. As he said, 'This is just the tip of the iceberg' [18].

\section{Electronic Duplicate Exchange Lists}

Also at the 1998 ALA Midwinter Meeting, Steve Johnson gave a presentation

on disposing of material through free electronic duplicate exchange lists. Libraries have traditionally associated informally to assist each other in disposing of unwanted serial back issues, while at the same time filling gaps in serials holdings. This method is also frequently used to find homes for unwanted books. Lists of duplicates are prepared and circulated among the group. Members mark their 'wants' and return the lists to the originator. The originator sends items at no charge to the first library responding. It is customary for the recipient to reimburse the originator for the postage. In 1994 Readmore, Inc. began offering free online serial duplicate and want lists via an unmoderated Internet mailing list (listserv) called BACKSERV

(<http://www.readmore.com/electron/backserv/backlist.html $>$ ). Using this service, libraries can perform the traditional duplicate exchange functions on the Internet more quickly, with less effort, and can reach a much wider audience. The following year Readmore expanded the scope to include books. In 1995 they also began BACKMED

(<http://www.readmore.com/electron/backserv/backmed.html >) the sister to BACKSERV, devoted to the listing of unneeded medical journal issues. BACKSERV and BACKMED now have more than 650 and 550 subscribers respectively with an average of nearly 50 messages a day per list. Some list members complain that they feel overwhelmed by the daily 'bombardment' of submissions [19].

Johnson also identifies a series of other electronic services:

- DEU-L <http://www.shsu.edu/ lib_www/deu/deu.html > 
- general duplicate exchange list begun in 1994 by the ALCTS Duplicates Exchange Union Committee

- searchable master index

- ASEE/ELD Duplicates Exchange $<$ http://www.ummu.umich.edu/library/ASEE/duplicates.html>

- maintained by the American Society for Engineering Education/Engineering Libraries Division

- focuses on engineering materials.

- NEEDSANDOFFERS-L <http://ftplaw.wuacc.edu/listproc/needsandoffers-1/ >)

- archives and lists legal materials

- Teri's WEB PALACE < $\underline{\text { http://www.mercer.edu/swilley/dupmain.htm }>}$

- maintained at Mercer University, Atlanta, GA.

- USBE (United States Book Exchange) $<\underline{\text { http://www.usbe.com/ }>}$

- a for-profit service [20]

\section{Serials Management Reports}

In the serials arena, the subscription agent's database is one of the most powerful tools available to collection development librarians charged with serials assessment. Standard bibliographic data have long been available including title, publisher, price, frequency etc. Today's databases include price history, subject categories, language, and indexing and abstracting information. Some databases include whether the title is peer reviewed, if the title is registered with the Copyright Clearance Center, and back issue information. For example, Faxon and EBSCO provide an extensive array of collection management reports. Faxon recently has formalized its collection development and analysis service with the title: Felix (Faxon Electronic Library Information Exchange). The core nine reports of the service can be produced in print or as an ASCII-delimited file for load into database management software. The following reports are available from at least one serials agent (the vendors who can provide this report as of 5/98 are noted in brackets) [21]:

1. Titles by Library of Congress classification-Faxon's version of this report can include just the library's titles or the entire universe of titles using the two-letter class code or the entire call number. There are summary reports as well as title by title reports. This report can be useful for institutions undergoing accreditation reviews. [Blackwell, EBSCO, Faxon]

2. Titles by local subject or department code [if the library provided and maintained these] - This report can include only those titles the library subscribes to or can include a list of all titles in a subject area including those currently not available at one's institution. [EBSCO]

3. Titles by country of origin-This report lists subscriptions by country or lists the entire 
universe of titles from a country. Faxon's comprehensive report also includes the number of orders they have for the title giving some indication of popularity. [Blackwell, EBSCO, Faxon]

4. Titles by language-Again this report is available for just the library's titles or the entire universe of titles. [Faxon]

5. Abstract and index report by title and by index (see Figures 3 and 4) - This report is useful for adding titles in support of a new discipline or canceling less useful titles. The report can be constructed as a list of titles indicating where they are indexed or a list of indexes with the titles included in them. The report also helps identify titles that are not indexed anywhere. [EBSCO, Faxon]

6. Listing by North American Title Count (NATC) categories-NATC was originally designed for measuring the strength of book collections; this report allows its use for serials by grouping LC call numbers into the NATC ranges. [Faxon] 


\begin{tabular}{|c|c|c|c|c|c|}
\hline \multicolumn{6}{|c|}{$\begin{array}{c}\text { Abstract \& Index Report by Index } \\
\text { Client Name: Sample Client }\end{array}$} \\
\hline $\begin{array}{l}\text { Abstact \& } \\
\text { Indexing } \\
\text { Name }\end{array}$ & AT Code & Title & Sub ID & Order Period & $\begin{array}{l}\text { Total amt w/o } \\
\text { Svc Chg }\end{array}$ \\
\hline \multirow{16}{*}{$\begin{array}{l}\text { Applied } \\
\text { Science \& } \\
\text { Technology } \\
\text { Index }\end{array}$} & \multirow[t]{16}{*}{ ST } & AIChE journal. & 739195 & $\begin{array}{l}\text { 01-Jan-1997 to } \\
\text { 31-Dec-1997 }\end{array}$ & $\$ 675.00$ \\
\hline & & Adhesives age. & 739197 & $\begin{array}{l}\text { 01-Apr-1997 to } \\
\text { 31-Mar-1998 }\end{array}$ & $\$ 57.00$ \\
\hline & & $\begin{array}{l}\text { American Chemical Society } \\
\text { Journal }\end{array}$ & 13787972 & $\begin{array}{l}\text { 01-Jan-1997 to 31-Jan- } \\
1998\end{array}$ & $\$ 1,700.00$ \\
\hline & & $\begin{array}{l}\text { Chemtech- (American } \\
\text { Chemical Society) }\end{array}$ & 58876739 & $\begin{array}{l}\text { 01-Feb-1997 to } \\
\text { 31-Jan-1998 }\end{array}$ & $\$ 910.00$ \\
\hline & & EC \& M. & 739186 & $\begin{array}{l}\text { 01-Jan-1997 to } 31 \\
\text { Dec-1997 }\end{array}$ & $\$ 30.59$ \\
\hline & & ENR & 739240 & $\begin{array}{l}\text { 01-Jan-1997 to31-Dec } \\
\text {-1997 }\end{array}$ & $\$ 74.00$ \\
\hline & & $\begin{array}{l}\text { Environmental science \& } \\
\text { technology- (American } \\
\text { Chemical Society) }\end{array}$ & 60973891 & $\begin{array}{l}\text { 01-Feb-1997 to } \\
\text { 31-Jan-1998 }\end{array}$ & $\$ 730.00$ \\
\hline & & $\begin{array}{l}\text { Journal of research of the } \\
\text { National Institute of Standards } \\
\text { and Technology }\end{array}$ & 739272 & $\begin{array}{l}\text { 01-Oct-1997 to } \\
\text { 30-Sep-1998 }\end{array}$ & $\$ 33.00$ \\
\hline & & Machine design with index & 739280 & $\begin{array}{l}\text { 01-Jan-1997 to } \\
\text { 31-Dec-1997 }\end{array}$ & $\$ 100.00$ \\
\hline & & Modern plastics & 739284 & $\begin{array}{l}\text { 01-Jan-1997 to } \\
\text { 31-Dec-1997 }\end{array}$ & $\$ 250.00$ \\
\hline & & & 739375 & $\begin{array}{l}\text { 01-Jan-1997 to } \\
\text { 31-Dec-1997 }\end{array}$ & $\$ 41.75$ \\
\hline & & $\begin{array}{l}\text { Plastics engineering-(Society of } \\
\text { Plastics Engineers) }\end{array}$ & 739306 & $\begin{array}{l}\text { 01-May-1997 to } \\
\text { 30-Apr-1998 }\end{array}$ & $\$ 125.00$ \\
\hline & & Plastics Technology & 739310 & $\begin{array}{l}\text { 01-Jan-1997 to } \\
\text { 31-Dec-1997 }\end{array}$ & $\$ 237.00$ \\
\hline & & Quality progress & 24273732 & $\begin{array}{l}\text { 01-Feb-1997 to } \\
\text { 31-Jan-1998 }\end{array}$ & $\$ 55.00$ \\
\hline & & Science (AAAS) & 739342 & $\begin{array}{l}\text { 01-Jan-1997 to } \\
\text { 31-Dec-1997 }\end{array}$ & $\$ 260.00$ \\
\hline & & Scientific American & 739344 & $\begin{array}{l}\text { 01-Jan-1997 to 31-Dec } \\
1997\end{array}$ & $\$ 39.95$ \\
\hline \multirow[t]{7}{*}{$\begin{array}{l}\text { Biological } \\
\text { Abstracts }\end{array}$} & \multirow[t]{7}{*}{ BA } & Advances in Polymer Science & 739199 & $\begin{array}{l}\text { Last part revd: Polymer } \\
\text { synthesis }\end{array}$ & $\$ 727.62$ \\
\hline & & $\begin{array}{l}\text { American Chemical Society } \\
\text { Journal }\end{array}$ & 13787972 & $\begin{array}{l}\text { 01-Jan-1997 to } \\
\text { 31-Dec-1997 }\end{array}$ & $\$ 1,700.00$ \\
\hline & & $\begin{array}{l}\text { Angewandte Chemie } \\
\text { International edition. With } \\
\text { Chemistry }\end{array}$ & 42099523 & $\begin{array}{l}\text { 01-Jan-1997 to } \\
\text { 31-Dec-1997 }\end{array}$ & $\$ 1,730.00$ \\
\hline & & Applied spectroscopy & 739203 & $\begin{array}{l}\text { 01-Jan-1997 to } \\
\text { 31-Dec-1997 }\end{array}$ & $\$ 290.00$ \\
\hline & & Atomic spectroscopy & 739185 & $\begin{array}{l}\text { 01-Jan-1997 to } \\
\text { 31-Dec-1997 }\end{array}$ & $\$ 52.00$ \\
\hline & & $\begin{array}{l}\text { Chemtech-(American Chemical } \\
\text { Society) }\end{array}$ & 58876739 & $\begin{array}{l}\text { 01-Feb-1997 to } \\
\text { 31-Jan-1998 }\end{array}$ & $\$ 910.00$ \\
\hline & & $\begin{array}{l}\text { Critical reviews in analytical } \\
\text { chemistry }\end{array}$ & 51537151 & v.26:no.1 1996 & $\$ 654.80$ \\
\hline
\end{tabular}

Figure 3. 


\begin{tabular}{|c|c|c|c|c|c|}
\hline \multicolumn{6}{|c|}{$\begin{array}{l}\text { Faxon Collection } \\
\text { Development } \\
\text { Report Series }\end{array}$} \\
\hline Title & Sub ID & Order Period & $\begin{array}{l}\text { Total Amt } \\
\text { w/o Svc Chg }\end{array}$ & $\begin{array}{l}\text { AI } \\
\text { Code }\end{array}$ & Abstract \& Indexing Name \\
\hline $\begin{array}{l}\text { AIChE } \\
\text { journal }\end{array}$ & 739195 & $\begin{array}{l}\text { 01-Jan-1997 to } \\
\text { 31-Dec-1997 }\end{array}$ & $\$ 675.00$ & $\begin{array}{l}\text { MR } \\
\text { PO } \\
\text { SC } \\
\text { EN } \\
\text { ST } \\
\text { AM } \\
\text { CA }\end{array}$ & $\begin{array}{l}\text { Mathematics Reviews } \\
\text { Pollution Abstracts } \\
\text { Science Citation Index } \\
\text { Engineering Index } \\
\text { Applied Science \& Technology Index } \\
\text { Mechanics Reviews } \\
\text { Chemical Abstracts }\end{array}$ \\
\hline $\begin{array}{l}\text { Adhesives } \\
\text { age. }\end{array}$ & 739197 & $\begin{array}{l}\text { 01-Apr-1997 to } \\
\text { 31-Mar-1998 }\end{array}$ & $\$ 57.00$ & $\begin{array}{l}\text { ST } \\
\text { EN } \\
\text { CA }\end{array}$ & $\begin{array}{l}\text { Applied Science \& Technology Index } \\
\text { Engineering Index } \\
\text { Chemical Abstracts }\end{array}$ \\
\hline $\begin{array}{l}\text { Advances in } \\
\text { polymer } \\
\text { science }\end{array}$ & 739199 & $\begin{array}{l}\text { Last part recvd: } \\
\text { Polymer synthesis }\end{array}$ & $\$ 727.62$ & $\begin{array}{l}\text { BA } \\
\text { SC } \\
\text { CA }\end{array}$ & $\begin{array}{l}\text { Biological Abstracts } \\
\text { Science Citation Index } \\
\text { Chemical Abstracts }\end{array}$ \\
\hline $\begin{array}{l}\text { Advances in } \\
\text { polymer } \\
\text { technology }\end{array}$ & 739200 & $\begin{array}{l}\text { 01-Jan-1997 to } \\
\text { 31-Dec-1997 }\end{array}$ & $\$ 568.00$ & $\begin{array}{l}\text { EN } \\
\text { CA }\end{array}$ & $\begin{array}{l}\text { Engineering Index } \\
\text { Chemical Abstracts }\end{array}$ \\
\hline $\begin{array}{l}\text { American } \\
\text { Chemical } \\
\text { Society } \\
\text { Journal }\end{array}$ & 13787972 & $\begin{array}{l}\text { 01-Jan-1997 to } \\
\text { 31-Dec-1997 }\end{array}$ & $\$ 1,700.00$ & $\begin{array}{l}\text { CA } \\
\text { SC } \\
\text { BA } \\
\text { ST } \\
\text { IM }\end{array}$ & $\begin{array}{l}\text { Chemical Abstracts } \\
\text { Science Citation Index } \\
\text { Biological Abstracts } \\
\text { Applied Science \& Technology Index } \\
\text { Index Medicus }\end{array}$ \\
\hline $\begin{array}{l}\text { Angewandte } \\
\text { Chemie } \\
\text { International } \\
\text { edition With } \\
\text { Chemistry }\end{array}$ & 42099523 & $\begin{array}{l}\text { 01-Jan-1997 to } \\
\text { 31-Dec-1997 }\end{array}$ & $\$ 1,730.00$ & $\begin{array}{l}\text { BA } \\
\text { CA } \\
\text { IC } \\
\text { IM }\end{array}$ & $\begin{array}{l}\text { Biological Abstracts } \\
\text { Chemical Abstracts } \\
\text { Index Chemicus } \\
\text { Index Medicus }\end{array}$ \\
\hline
\end{tabular}

Figure 4.

7. Claims history report-This report is intended to help a library determine the maintenance level a title will require, if it is continually delayed or behind schedule. [EBSCO]

8. Titles received as a part of a membership-This report is useful for determining what titles may be effected if the membership were cancelled, whether a title might more economically be purchased individually or as part of a membership (if possible). [EBSCO, Faxon]

9. Titles ordered from particular suppliers (Neodata) and publishers-This report is useful today because the information is often difficult to extract from bibliographic records and is not routinely kept up to date as titles are purchased by different publishers. OSU has needed this publisher information to determine the titles owned by OSU for OhioLINK full text deals such as Academic or Elsevier to determine the correct pricing basis for full text 
deal. [Blackwell, EBSCO, Faxon]

10. Titles registered with the Copyright Clearance Center-This is an easy way to determine which titles are registered with the CCC for royalty payment purposes. [EBSCO, Faxon expects to add in the future]

11. Historical price analysis reports - Generally, this report covers a 3- to 5-year span and can be sorted or produced by categories such as publisher, subject, department or fund code.

Some vendors such as EBSCO can provide this report on disk so that the library can do its own sorting and manipulation, e.g., sorting titles by highest percentage of increase over the 5-year time period [Blackwell, EBSCO]

12. Inflation projection report - This report projects inflation by geographical region for the titles subscribed to by the library. [EBSCO, Faxon]

13. Survey report for customers (see Figure 5) - This report is a list of titles for review with a 5-point rating scale printed on the report. This allows the report to be sent to faculty members as a survey of journal importance. The report can include pertinent information such as price and publisher and can be sorted so that particular subsets can be sent to particular faculty i.e., by subject. [EBSCO]

14. Subscriptions within a region or consortium - This report summarizes ownership of journals by libraries in a region or consortium subject to usage of the same vendor for the various libraries [EBSCO]

15. Existing print subscriptions matched against vendor's electronic journal database (see Figure 6) - This report helps a library determine what is available electronically with detailed pricing information. A comprehensive list of all electronic journals available through Faxon is also available. [Faxon]

16. An indicator of the peer-review status of the journal [Faxon - to be added in the future]

17. An indicator of titles available from Minority or Women Business Enterprises [Faxon-to be added in the future]

Certainly, some of this information may be more readily available from the local library system particularly if all serials are not consolidated with a single vendor, but rarely is all of this information available from the local system.

There may be a significant advantage in the future to consolidating all subscriptions whether paper, electronic, or via document delivery with a single agent. In such a scenario, consolidation (particularly for the electronic and document delivery approaches) would allow the agent to evaluate library (and individual patron) usage of these various types of subscriptions to determine the optimum combination of purchase and access. Dixon Brooke of EBSCO has speculated that:

\section{SERIALS COLLECTION DEVELOPMENT}

\section{Survey Report for Customer Titles}

Description: List of titles including ISSN, publisher, country of origin, indexing, language, and peer review information coupled with a five point rating scale.

\section{Uses/Benefits:}

- Allows customers to seek input from the faculty or subject bibliographers in order to evaluate the 
importance of a journal to the collection.

- Titles can be ranked on a scale from one to five signifying the importance of each to the faculty member or bibliographer.

- Rankings can be combined with other evaluative criteria selected by the librarian or criteria from EBSCO Subscription Data Diskette for computer manipulation.

- Librarians often want to combine the selection criteria, journal usage, and faculty ranking in order to evaluate a title.

- Provides an easy management tool for librarians to involve faculty and other librarians responsible for collecting in the various subject areas.

- Provides the total cost by each department or fund code, including the cost of the priced titles and the average price per title.

Report No: SPBC315-R1B

EBSCO Subscription Services

Survey Report For Customer Titles BY: HEGIS 06/15/94 TO 01/04/95
EBSCO

Subscription Services A part of the EBSCO Information Services group RUN DATE: 02/24/xx CURRENCY: US

CUSTOMER ES 00000-00

HOW IMPORTANT IS THIS LIBRARY SUBSCRIPTION To YOUR RESEARCH AND/OR TEACHING?

(PLEASE CIRLCE YOUR RESPONSE FOR EACH JOURNAL)

HEGIS: 00CHEM

TITLE NAME

VIBRATIONAL SPECTROSCOPY /FOR THE AMERICAS/

INDEX CODES: AA AR EG

FZ HS MR QG RN RQ

\section{PWP $=$ PRICED WHEN PUBLISHED}

ISSN/TITLE \#

RATE

PWP

0924-2031

932-772-205

PEER REVIEWED/REFERED

ZEITSCHRIFT FUER ANORANISCHE UND ALLGEMEINE CHEMIE /FOR NORTH AMERICA/ *SQ

ZEITSCHRIFT FUR NATURFORSCHUNG /PART B/ JOURNAL OF CHEMICAL SCIENCES INDEX CODES: FZ HS MR

ZEITSCHRIFT FUER PHYSIKALISCHE CHEMIE /INTL JRNL OF IN PHYSICAL CHEMISTRY \& CHEMICAL PHYSICS/
$976-625-020$ ON OQ RN RQ
0932-0776 978-625-087 ISI I-F /1991/ 0.928

0044-3336 978-884-047
$\$ 674.00$

PWP

\section{TOTALS}

NUMBERS OF TITLES............ NUMBER OF PRICED TITLES...... COST OF PRICED TITLES....... AVERAGE PRICE PER TITLE

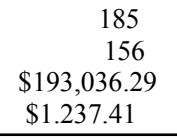

Figure 5. 


\begin{tabular}{|c|c|}
\hline \multicolumn{2}{|c|}{$\begin{array}{lc}\text { Faxon Collection } & \text { Client Titles Available In Electronic Format } \\
\text { Development } & \text { Client name: Sample client } \\
\text { Report Series } & \end{array}$} \\
\hline Current Order Information & Electronic Journal Information \\
\hline Bulletin of the history of Medicine. & Bulletin of the History of Medicine \\
\hline $\begin{array}{llc}\text { Sub ID: } & 253972 & \text { Quantity: } 1 \\
\text { Order period: } & 01-J a n-1998 \text { to 31-Dec-1998 } \\
\text { Catalog ID: } 185188 & \text { ISSN: 00075140 } \\
\text { Supplier 555040 } & \text { Johns Hopkins Univ. Press } \\
\text { URL: http://muse.jhu.edu/journals/bulletin_of } \\
\text { _the_history_of_ }\end{array}$ & $\begin{array}{l}\text { Cost: } * 75.60 \text { online, } \$ 84.00 \text { print } \\
\text { Comments: } \$ 109.20 \text { for both print } \$ \text { online. Project Muse } \\
\text { print price } \$ 33.60 \text {. }\end{array}$ \\
\hline $\begin{array}{l}\text { Callaloo } \\
\text { Sub ID: 254012 Quantity: } 1 \\
\text { Order period 01-Jan-1998 to 31-Dec-1998 } \\
\text { Catalog ID: 103909 ISSN: 01612492 } \\
\text { Supplier: 555040 Johns Hopkins Univ Press } \\
\text { URL: http://muse.jhu.edu/journals/callaloo }\end{array}$ & $\begin{array}{l}\text { Callaloo } \\
\text { Cost: } * 67.50 \text { online, } \$ 75.00 \text { print } \\
\text { Comments: } \$ 97.50 \text { for both print and online. Project Muse } \\
\text { print price } \$ 30.00\end{array}$ \\
\hline 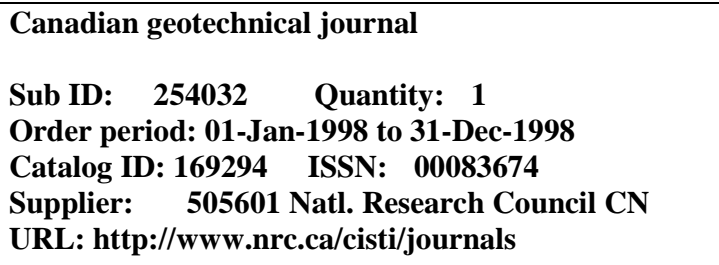 & $\begin{array}{l}\text { Canadian Geotechnical journal } \\
\text { Cost: } \$ 285.00 \text { print, online free on } \\
\text { Comments: At present online access is free to anyone per } \\
\text { sub call } 4 / 23 / 97\end{array}$ \\
\hline $\begin{array}{l}\text { Canadian journal of civil engineering } \\
\text { Sub ID: } 254039 \text { Quantity: } 1 \\
\text { Order period 01-Jan-1998 to 31-Dec-1998 } \\
\text { Catalog ID: } 190754 \quad \text { ISSN: 03151468 } \\
\text { Supplier: } 505601 \quad \text { Natl Research council CN } \\
\text { URL: http://www.nrc.ca/cisti/journals/cjfasf.html }\end{array}$ & $\begin{array}{l}\text { Canadian journal of civil engineering } \\
\text { Cost: } \$ 363.00 \text { print, online free on } \\
\text { Comments: At present online access if free to anyone per } \\
\text { sub call } 4 / 23 / 97\end{array}$ \\
\hline $\begin{array}{l}\text { Canadian Journal of fisheries and aquatic sciences } \\
\text { Sub ID: } 254047 \quad \text { Quantity: } 1 \\
\text { Order Period: } 01-J a n-1998 \text { to } 31 \text {-Dec-1998 } \\
\text { Catalog IDL } 217088 \quad \text { ISSN: 0706652X } \\
\text { Supplier: } 505601 \quad \text { Natl Research Council CN } \\
\text { URI: http//www.nrc.ca/cisti.journals }\end{array}$ & $\begin{array}{l}\text { Canadian journal of fisheries and aquatic sciences } \\
\text { Cost: } \$ 461.00 \text { print, online, o/s } \\
\text { Comments: As of } 5 / 15 / 97 \text {, online only available to print } \\
\text { subsr., online only not avail. }\end{array}$ \\
\hline $\begin{array}{l}\text { Canadian journal of forest research } \\
\text { Sub ID: } 254048 \quad \text { Quantity: } 1 \\
\text { Order period 01-Jan-1998 to 31-Dec-1998 } \\
\text { Catalog ID: } 185830 \quad \text { ISSN: 00455067 } \\
\text { Supplier: 505601 Natl Research Council CN } \\
\text { URL: http://www.nrc.ca/cisti/journals }\end{array}$ & $\begin{array}{l}\text { Canadian journal of forest research } \\
\text { Cost: } \$ 462.00 \text { print, online free on } \\
\text { Comments: At present online access is free to anyone per } \\
\text { pub call } 4 / 23 / 97\end{array}$ \\
\hline Canadian journal of physics & Canadian journal of physics \\
\hline $\begin{array}{l}\text { Sub ID: } 254059 \text { Quantity: } 1 \\
\text { Order period 01-Jan-1998 to 31-Dec-1998 } \\
\text { Catalog ID: } 162712 \quad \text { ISSN: } 00084204 \\
\text { Supplier: 505601 Natl Research Council CN } \\
\text { URL: http//www.nrc.ca/cisti/journals }\end{array}$ & $\begin{array}{l}\text { Cost: } \$ 374.00 \text { print, online free on } \\
\text { Comments: At present online access is free to anyone per } \\
\text { pub call } 4 / 23 / 97\end{array}$ \\
\hline
\end{tabular}

Figure 6. 


\begin{abstract}
If one agency is used for most subscriptions, licenses, access and document delivery services, that agent should be in a good position to help the library arrive at a precise formula for the least expensive, most efficient information provision. The library and vendor together should be able to identify: high-use or low-cost journals appropriate for subscriptions or licenses; extremely time-sensitive materials that might necessitate Web access/subscriptions; and high-cost or low-use journals that might be better candidates for current awareness/document delivery services or full text access via online hosts. The agency's services should include ongoing analysis so the library can shift resources as needed to continue to control costs and maximize access. For example, ongoing analysis of document delivery purchases or of articles printed from an online host might indicate when it would actually be more cost effective to subscribe to a more expensive journal [22].
\end{abstract}

Another approach is embodied in Faxon's Information Quest (IQ). This service provides access to electronic journals from publishers such as Blackwell Science, Kluwer Academic, and MIT Press. With this system, a user can retrieve a article in four ways (depending on the choices made by the library): subscription to the electronic journal, order via document delivery, pay-per-view, and a link to the library catalog to display availability of paper copy holdings.

As a final example of a service a serials agent can provide, Georgia Institute of Technology began a long term journal use study in March 1996. Their intent was to identify heavily used portions of the serial collection to augment and to support cancellation decisions in lesser used areas. EBSCO supplied them with subscription data on diskette that they loaded into a Microsoft Access database. The database information included title, ISSN, frequency, price, publisher, country of origin, language, and LC Class. EBSCO also supplied barcode labels for each title with the ISSN. These were attached to the shelves for each title. As each title was reshelved, a portable barcode scanner was used to scan the ISSN barcode on the shelf. The barcode was scanned once for each issue reshelved. At the end of each day, the data were downloaded into the database. Then the data could be manipulated by the database software to create a variety of reports [23].

\title{
Document Delivery Services
}

Tina Chrzastowski and Mary Anthes of the University of Illinois Chemistry Library conducted a $6^{1} / 2$ month study of document delivery in 1995 . Their collection had previously been established as supplying $90 \%$ of the journals needed by users.

The needs expressed through ordering articles the library did not own [via document delivery services] represented an excellent opportunity to find out what patrons needed beyond the $90 \%$ level. [In their study], records were kept on each title requested. . . Only three journals (out of 136 unique titles) had requests for four articles each; 27 titles had requests for two or three articles. The majority of requests were for a single article from a single journal title. ... This finding shows how cost ineffective it would be to purchase subscriptions for any of these subscriptions with most journals having only one use during the $6 / 2$ month study period [24].

Many subsequent document delivery studies have supported these findings. As vendor document delivery services have matured, reports from the vendor with this sort of information have become available to users (without having to do a study such as Chrzastowski and Anthes'). For example, UnCover provides detailed information such as the user's name, department, document citation, costs, number of pages, delivery method and date and time the order was placed and shipped. This 
information can be provided electronically making it easier for the library to compile a local database summarizing the information. The University of Kansas has provided UnCover's service to its users for the past 2.5 years. KU has constructed an extensive database of information concerning their document delivery experiences and, in some areas, enriched with interlibrary loan information. As a result, the library can compare information on which part of the database (table of contents or citation searching) was used to identify the needed article, what departments on campus were the heaviest users, the costs involved in supplying the titles, the projected costs for subscribing to the title in lieu of document delivery, the method of delivery such as fax or mail, the fill rate, and the turnaround time. UnCover's system supports seven library-defined fields of information for each order placed using the library's account. Information such as internal division or department name, project number, federal grant number, academic department, and staff ID number can be gathered and reported monthly. These statistical reports can be sorted and sub-sorted using any of this stored information [25]. Because many of these services have been developed by subscription agents, it is an easy matter to summarize the usage by title and include information on the pricing. Over and over again, libraries find an isolated title that might warrant a subscription, but for the most part, libraries find that the use of document delivery is far more economical for these particular titles rather than subscription. Again, this is an example of a service used by libraries to extend the resources available to the patrons, which includes rich management information for collection assessment. Such information also informs choices for retention and cancellation of titles.

\section{Aggregator Services for Electronic Journals}

The usage statistics available for document delivery are also becoming available for electronic journal usage. Most major subscription agents have available and are touting the benefits of what are know as "aggregator systems." In these systems, the serials vendor licenses the full text of journals published by a variety of publishers and makes them available through a standard interface. Such systems have opened entire new horizons about the actual usage of journals and particularly the individual articles within a journal. As with document delivery services, these systems are able to track what journals are used, which articles within those journals are used, and by whom. When supplied by a subscription agent, it should be relatively easy to include cost information for print subscriptions (and electronic ones) into a standard report. For OSU, OhioLINK has contracted for the full text of journals from Academic Press and Elsevier with negotiations ongoing with other publishers. OhioLINK expects to include usage information on these titles by institution on a portion of their staff Web page. In addition, OSU has been writing into all of its electronic licenses and contracts a provision that the vendor supply usage data. Of course, no one knows how each vendor will provide this and how the library will gather and analyze it, but this approach is at least a start. However, libraries already receive regular usage reports from at least one supplier, Project Muse at Johns Hopkins University. Project Muse sends subscribers a quarterly usage report via e-mail. Extraneous hits to buttons and boilerplate information have been removed to avoid artificially inflated statistics. The report includes a listing of journal titles with title-specific information on number of hits to the full text articles, to graphics and images, and to tables of contents [26].

\section{CONCLUSION}

As this paper reveals, much progress has been made since 1992 in the services and 
products that vendors and agents can provide in support of collection management. This also confirms the continued viability and importance of vendors and agents to libraries. A list of useful Web sites is included as Appendix A. Let me leave you with three thoughts for further contemplation:

1. What impact would it have on library operations - particularly positive ones - to explore options such as a Web database from a vendor to allow collection managers to place many of their orders directly online with the vendor?

2. What lessons should academic libraries learn from public colleagues about fulfilling user demands, speed of supply, and anticipating requests from users?

3. What impact would it have on library operations - particularly positive ones - if libraries consolidated all print and electronic serials subscriptions and document delivery with a single vendor?

\section{APPENDIX A: USEFUL WEB SITES}

\section{Monographic Services}

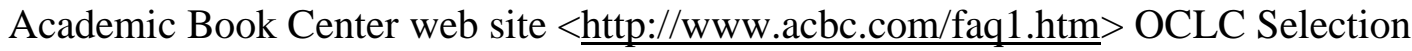
$<$ http://www.oclc.org/menu/selection.htm $>$ Yankee Book Peddler web site $<$ http://www.ybp.com/gobi/>

Out of Print Book Services

Advanced Book Exchange (ABE) $\langle$ http://www.abebooks.com $>$

Interloc $<$ http://www.interloc.com $>$

Bibliofind $<$ http://www.bibliofind.com $>$

MX Bookfinder <http://www.mxbf.com $>$

\section{Electronic Duplicate Exchange Lists}

BACKSERV <http://www.readmore.com/electron/backserv/backlist.html $>$

BACKMED <http://www.readmore.com/electron/backserv/backmed.html $>$

DEU-L <http://www.shsu.edu/ lib_www/deu/deu.html >

ASEE/ELD Duplicates Exchange

$<$ http://www.ummu.umich.edu/library/ASEE/duplicates.html $>$

NEEDSANDOFFERS-L <http://ftplaw.wuacc.edu/listproc/needsandoffers-l/>

Teri's WEB PALACE < http://www.mercer.edu/swilley/dupmain.htm>

USBE (United States Book Exchange) <http://www.usbe.com/ $>$

Serial Management Reports

Blackwells <http://www.blackwell.co.uk/journals/subserv/>

Faxon <http://www.faxon.com $>$

EBSCO <http://www.ebsco.com/ $>$

\section{Document Delivery and Aggregator Systems}

Blackwells <http://www.blackwell.co.uk/journals/subserv/docdel.html $>$

EBSCO <http://www.ebsco.com/ $>$

Faxon $\langle$ http://www.faxon.com $>$ 
UnCover < $\underline{\text { http://uncweb.carl/org/> }}$

\section{REFERENCES}

1. Hawks, Carol P. "In Support of Collection Assessment: The Role of Automation in the Acquisitions and Serials Departments," Journal of Library Administration, 17 (1992), 13-30.

2. Barker, Joseph W. “Acquisitions and Collection Development: 2001,” Library Acquisitions: Practice \& Theory 12 (1988) 243-246.

3. Alessi, Dana L. "Me and My Shadow: Vendors as the Third Hand in Collection Evaluation," Journal of Library Administration, 17 (1992), 55.

4. Academic Book Center web site <http://www.acbc.com/faq1.htm $>$.

5. Most of the major book vendors have similar systems available or are in the process of developing them.

6. OhioLINK Approval Plan Vision, February 16, 1998, unpublished document.

7. Association of Research Libraries, Office of Management Services. Collection Description and Assessment in ARL Libraries, SPEC Kit 87. Washington, DC: Association of Research Libraries, 1982, first unnumbered page.

8. Quinn, Judy. "The New Approval Plans: Surrendering to the Vendor. . . or in the Driver's Seat?" Library Journal, 116 (September 15, 1991), 38.

9. Gibson, Catherine. "How We Spent \$2.7 Million-With the Help of Centralized Selection," Library Journal, 120 (September 1, 1995), 128.

10. Lee, Lauren, K. "Library/Vendor Cooperation in Collection Development," The Acquisitions Librarian, 5 (1991), 183.

11. Lee, Lauren, K. "Library/Vendor Cooperation in Collection Development," The Acquisitions Librarian, 5 (1991), 186.

12. Quinn, Judy. "The New Approval Plans: Surrendering to the Vendor ... or in the Driver's Seat?" Library Journal, 116 (September 15, 1991), 40.

13. OCLC Selection Web site <http. //www.oclc.org/menu/selection.htm $>$.

14. Yankee Book. Peddler web site <http://www.ybp.com/gobi/>.

15. E-mail message from Rick Lugg, Yankee Book Peddler (May 4, 1998).

16. Johnson, Steve. "Needle in the Bookstack: Web Solutions for Finding Out-of-Print Titles." Library Acquisitions: Practice \& Theory, 22 (1998), 371.

17. Johnson, Steve. "Needle in the Bookstack: Web Solutions for Finding Out-of-Print Titles." Library Acquisitions: Practice \& Theory, 22 (1998), 371.

18. Johnson, Steve. "Needle in the Bookstack: Web Solutions for Finding Out-of-Print Titles." Library Acquisitions: Practice \& Theory, 22 (1998), 371.

19. Bybee, Howard C, and Johnson, Steve. "Selling, and Exchanging Unselected, and Duplicate." Gifts on the Internet. Library Acquisitions: Practice \& Theory, 22 (1998), 373.

20. Bybee, Howard C, and Johnson, Steve. "Selling, and Exchanging Unselected, and Duplicate." Gifts on the Internet. Library Acquisitions: Practice \& Theory, 22 (1998), 373.

21. Born, Kathleen. "The Role of the Serials Vendor in the Collection Assessment and Evaluation Process," Journal of Library Administration, 19(1993), 125-38.

22. Brooke, F. Dixon. "Subscription or Information Agency Services in the Electronic Era," 
The Serials Librarian, 29 (1996), 64-65.

23. Macklin, Lisa. “A Journal Use Study Made Easier," At Your Service, 39 (Jan/Feb/March 1997) Macklin, Lisa. “A Journal Use Study Made Easier with Bar Codes: Collecting Data and Running Reports," At Your Service 41 (Aug/Sept/Oct 1997): 〈http://www/ebsco/com/ess/news/ays/41bar.asp >.

24. Chrzastowski, Tina E., and Anthes, Mary. (1995). "Seeking the $99 \%$ Chemistry Library, Extending the Serial Collection Through the use of Decentralized Document Delivery," Library Acquisitions: Practice \& Theory, 19 (1995), 149.

25. UnCover Web Page <http. //uncweb.carl.org/uncover/ccenters.html>.

26. “MUSE Stats. Quarter 1, 1998,” E-mail message from Wendy McFarland, Project Muse, (May 4, 1998). 